\title{
Technè
}

La science au service de l'histoire de l'art et de la préservation des biens culturels

$48 \mid 2019$

Les couleurs de l'Antique

\section{Tracing the colours of Hermogenes' temple of Artemis: architectural surface analysis in the Antikensammlung Berlin}

Les couleurs retrouvées du temple d'Artémis construit par Hermogène: analyse de surface architecturale dans la Collection des antiquités de Berlin

Stephan Zink, Moritz Taschner, Ina Reiche, Matthias Alfeld, Cristina Aibéo, Ellen Egel, Katharina Müller, Anne Ristau, Birgit Neuhaus and Wolfgang Massmann

\section{OpenEdition}

Electronic version

URL: https://journals.openedition.org/techne/1791

DOI: 10.4000/techne.1791

ISSN: 2534-5168

Publisher

C2RMF

Printed version

Date of publication: 31 December 2019

Number of pages: $14-26$

ISBN: 978-2-11-152831-4

ISSN: 1254-7867

\section{Electronic reference}

Stephan Zink, Moritz Taschner, Ina Reiche, Matthias Alfeld, Cristina Aibéo, Ellen Egel, Katharina Müller, Anne Ristau, Birgit Neuhaus and Wolfgang Massmann, "Tracing the colours of Hermogenes' temple of Artemis: architectural surface analysis in the Antikensammlung Berlin", Technè [Online], 48 | 2019, Online since 01 July 2021, connection on 02 April 2022. URL: http://journals.openedition.org/techne/ 1791 ; DOI: https://doi.org/10.4000/techne.1791

\section{(c) (ㅇ) $\odot$}

La revue Technè. La science au service de l'histoire de l'art et de la préservation des biens culturels est mise à disposition selon les termes de la Licence Creative Commons Attribution - Pas d'Utilisation Commerciale - Pas de Modification 4.0 International. 


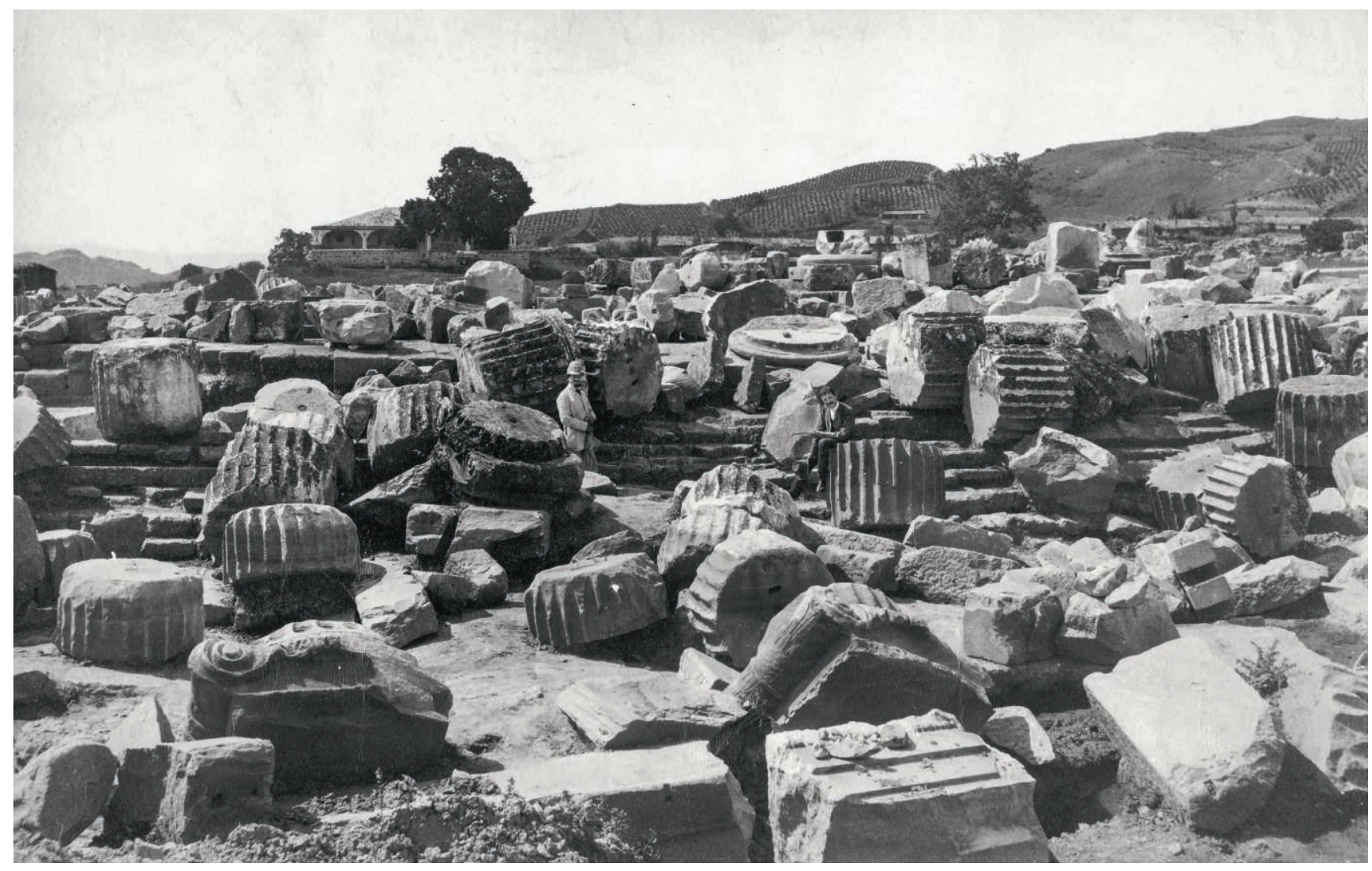

Fig. 1. Carl Humann (left) and Julius Kohte (right) amidst the architectural remains of the Temple of Artemis Leukophryene in 1891. (c) Archive of the Antikensammlung, Staatliche Museen zu Berlin (FA-Mag 01b-0005). 
Stephan Zink

Moritz Taschner

Ina Reiche

Matthias Alfeld

Cristina Aibéo

Ellen Egel

Katharina Müller

Anne Ristau

Birgit Neuhaus

Wolfgang Massmann

\section{Tracing the colours of Hermogenes' temple of Artemis: architectural surface analysis in the Antikensammlung Berlin}

Les couleurs retrouvées du temple d'Artémis construit par Hermogène : analyse de surface architecturale dans la Collection des antiquités de Berlin
Abstract. The temple of Artemis at Magnesia on the Maeander (Western Turkey) is a milestone of Hellenistic architecture. Its architect, Hermogenes of Priene, was famously praised as an innovator already in Antiquity. While we know a good deal on the temple's architecture, its accentuation with colour remains unknown. A collaborative research project in the Antikensammlung Berlin has now investigated three large marble fragments of the temple's exterior façade for the remains of colour coatings. Using multiple methods of microscopic and physicochemical analysis, it was possible, for the first time, to provide an insight into the temple's exterior colour accentuations. It seems that the façade featured a colour scheme, in which white and yellowbrown hues played a key role, the latter probably for the painterly imitation of freshly cast or gilded bronze applications. Painted shading and colour highlights, applied with a careful consideration for spatial context and light conditions, completed the design. This is the first such evidence on a monumental temple façade. Remarkably, the applied design departs from the traditional colour triad of white, blue and red that was applied on many previous and contemporary temple facades throughout the Classical World. It imitates, however, a tradition of metal decoration that was a hallmark of sacred architecture.

Keywords. Hellenistic architecture, Ionic temple, columnar order, column capital, colour, polychromy, painting on marble, Hermogenes, temple of Artemis Leukophryene, Magnesia on the Maeander, material imitation, pseudodipteros.
Résumé. Le temple d'Artémis à Magnésie du Méandre, dans l'actuelle Turquie occidentale, est un jalon de l'architecture hellénistique. Nous savons que son créateur, Hermogène de Priène, était déjà salué dans l'Antiquité pour ses innovations. Malgré notre bonne connaissance de l'architecture même du temple, nous n'avions aucune information sur les applications de couleur. Un travail de recherche conduit en équipe dans la Collection des antiquités de Berlin a mis en évidence des traces de revêtement coloré sur trois grands fragments de marbre de la façade extérieure. Le recours à plusieurs méthodes d'analyse microscopique et physicochimique a livré pour la première fois un aperçu de l'accentuation par la couleur de l'extérieur du temple. Le schéma de mise en couleur de la façade présentait apparemment une prédominance de tons blanc et jaune-brun, ces derniers servant sans doute à imiter par la peinture des éléments appliqués en bronze fraîchement coulé ou doré. Des effets picturaux d'ombre et de rehauts de lumière, traduisant un grand souci de l'espace et des conditions d'éclairage, agrémentaient l'ensemble. C'est le premier décor de ce type jamais découvert sur une façade de temple monumentale. Il s'écarte notablement de l'habituel schéma ternaire blanc, bleu et rouge rencontré sur de nombreuses façades de temples plus anciens ou contemporains à travers le monde classique. Il sinspire en revanche d'une tradition de décoration métallique propre à l'architecture sacrée.

Mots-clés. Architecture hellénistique, temple ionique, ordre de colonnes, chapiteau, couleur, polychromie, peinture sur marbre, Hermogène, temple d'Artémis Leucophryène, Magnésie du Méandre, imitation de matières, pseudodiptère.

Stephan Zink, Swiss National Science Foundation and Berliner Antike Kolleg (2015-17); German Archaeological Institute Berlin, Department of Building Archaeology (since 2017) (stephan.zink@dainst.de). Moritz Taschner (m.taschner@smb.spk-berlin.de); Birgit Neuhaus (birgitnhs@gmail.com); Wolfgang Massmann (w.massmann@smb.spk-berlin.de), Antikensammlung, Staatliche Museen zu Berlin, Stiftung Preußischer Kulturbesitz. Ina Reiche, Rathgen-Forschungslabor, Staatliche Museen zu Berlin, Stiftung Preußischer Kulturbesitz; PSL Université, ENSCP, Institut de recherche de Chimie Paris UMR 8247 CNRS - C2RMF, Paris (ina.reiche@ chimieparistech.psl.eu). Matthias Alfeld, Laboratoire d'Archéologie Moléculaire et Structurale, UMR 8220 CNRS, Sorbonne Université, Paris; Delft University of Technology, Materials Science and Engineering (3mE) (M.Alfeld@tudelft.nl). Cristina Aibéo (c.aibeo@smb. spk-berlin.de); Ellen Egel (ellen.egel@bldam-brandenburg.de), Rathgen-Forschungslabor, Berlin. Katharina Müller, Laboratoire d'Archéologie Moléculaire et Structurale, UMR 8220 CNRS, Sorbonne Université, Paris; IPANEMA, Synchrotron SOLEIL, USR 3461 CNRS, Ministère de la Culture, Université Versailles Saint-Quentin-en-Yvelines (katharina.muller@synchrotron-soleil.fr). Anne Ristau, Antikensammlung, Staatliche Museen zu Berlin; HTW, University of Applied Sciences for Engineering and Economics Berlin (anneristau@yahoo.de). 
The marble temples of the Greco-Roman world were accentuated with colour. While this is a well-known fact since the 19th century, our knowledge of the technical and artistic variety of architectural surface coating remains limited, especially when it comes to monumental marble facades ${ }^{1}$. Often, erosion and weathering left no trace of former colouring. Therefore, freshly excavated architectural members or those that were placed in museums directly after excavation and not drastically cleaned offer the best chance to gain new information on the colouring of monumental marble facades. This was the premise for a collaborative one-year pilot-project that was carried out in 2015 and 2016 at the Antikensammlung Berlin with funding of the "Berliner Antike Kolleg" and the "Einstein Foundation Berlin"? The project's goal was to investigate the potential of Berlin's unique collection of ancient architectural marbles for future research on polychromy. To this end, the surfaces of three architectural members in white marble were examined in an in-depth surface analysis. This contribution presents the synthesized results of our project and briefly discusses them within the wider context of ancient architectural polychromy.
The three architectural pieces come from the exterior façade of the temple of Artemis Leukophryene at Magnesia on the Maeander (Western Turkey). It was built during the first decades of the 2nd century B.C. and designed by the Ionian architect Hermogenes, as we learn from the Roman architectural theorist Vitruvius, who also praised the temple's innovative design (De Architectura, 3.2.6; 3.3.8-9). Based on the temple's substantial remains, scholars have pointed out that indeed Hermogenes broke new ground with this building, in particular with his masterful exploitation of an entire repertoire of spatial and visual effects ${ }^{3}$. The results of our project give us, for the first time, a glimpse into the role of colour in the temple's intricate design concept. This is even more remarkable when considering that the seminal publication of 1904 concluded that the remains of the temple preserved no evidence of colour ${ }^{4}$.

Based on both microscopic examination and scientific methods of elemental analysis, we were able to identify traces of colour coatings on all of the three marble fragments. A variety of pigment mixtures can be suggested (so far, analysis to detect binders was not carried out). The data, even if

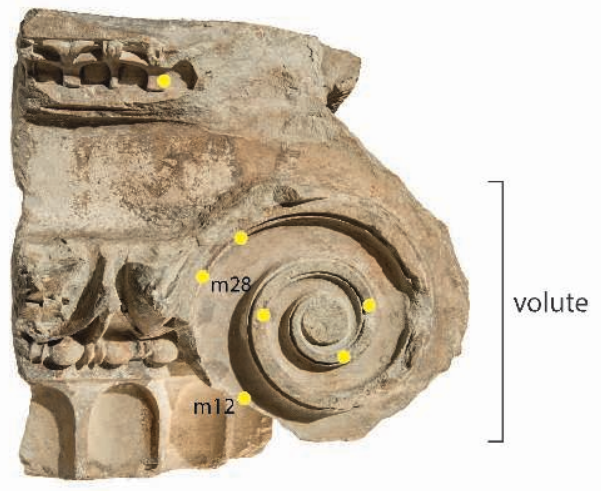

Fgmt. A front

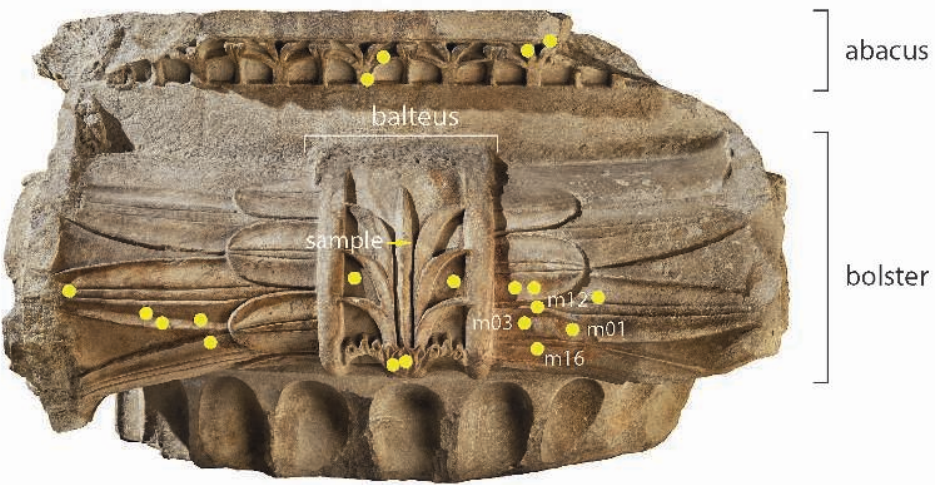

Fgmt. A side (I. 1.44; h. 0.81 m)

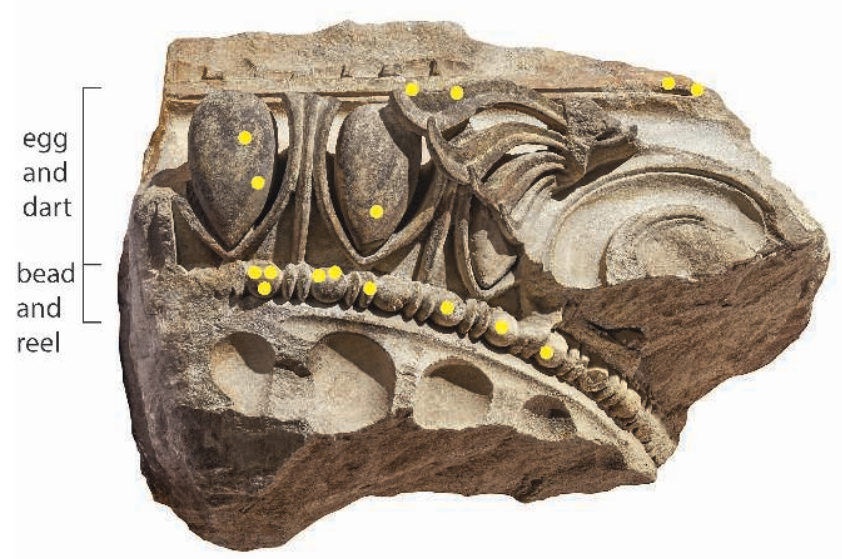

Fgmt. B (I. 1.06; h. 0.73 m)

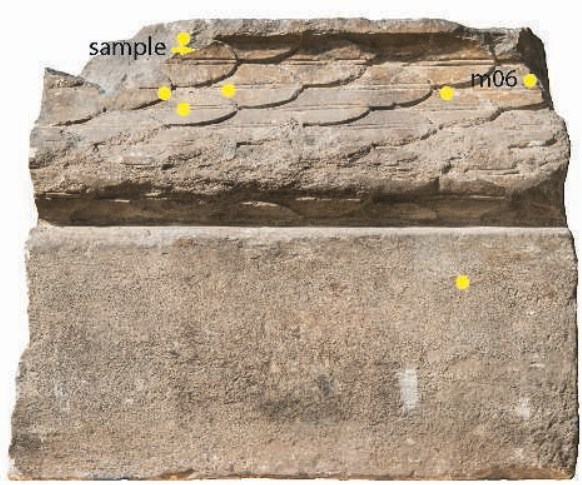

Fgmt. C (l. 0.71; h. $0.58 \mathrm{~m})$

Fig. 2. The three architectural members which were investigated in the course of this project: two fragments of Ionic capitals (A, B) from the exterior columnar order and a fragment from the base of the cella wall $(\mathrm{C})$. The yellow dots indicate the locations of microscopic examination (photos not to scale). (c) Antikensammlung, Staatliche Museen zu Berlin/A. Paasch. 
selective, suggests that the temple's exterior colour scheme favored white surfaces and, on architectural ornaments, various yellow-brown hues. Both the colouring and the painting technique suggest that they were meant to imitate freshly cast or gilded bronze. As it seems, the artists who painted the temple applied the full palette of painterly colour rendering such as naturalism, shading, and highlighting. Contour and shadow lines were set with respect to show sides and light impact. This intricate surface rendering may well have been part of the façade's original design concept.

\section{Provenance and prior handling of the fragments}

The provenance of the Berlin fragments leads us back to Prussian archaeology of the late 19th century. Between March 1891 and July 1893, the German railroad engineer and architect Carl Humann directed the archaeological excavations at the site of Magnesia on behalf of the "Königliche Museen zu Berlin", together with the philologist and archaeologist Otto Kern and the architect Rudolf Heyne (fig. 1$)^{5}$. At the end of the expedition, about 200 architectural pieces of the Magnesian temple of Artemis were transported to Berlin, where they were integrated into the "Antikensammlung". Two thirds of this material belonged to the acroteria ${ }^{6}$; the rest, about 60 pieces, were strategically chosen samples of decorated architectural surfaces from all parts of the temple.

Also among the pieces brought to Berlin were the three fragments in white marble, which are at the focus of our project (fig. 2, 3): one half of an Ionic capital, which includes the upper end of a fluted column shaft and a nearly complete bolster (balteus) with palm leaf decoration (henceforth fragment A; Museum inv. V1.2-7); a quarter of an Ionic capital, which preserves parts of the echinus that was decorated with a deeply undercut egg and dart molding (henceforth fragment B; Museum inv. V1.2-8); and a block from the base of the cella wall, decorated with a leaf pattern (henceforth fragment C; inv. V1.3-46) ${ }^{7}$. As usual during the 19th century, all of these pieces were re-cut before transportation to reduce weight - what counted were the decorated surfaces.

The three fragments presented here were selected because they all belong to the temple's exterior and show quite heterogeneous surface phenomena ${ }^{8}$. Unlike the pieces that are still at the site today, they had never been exposed to post-excavation weathering as they were brought to the storage rooms of Berlin immediately upon excavation. Later, after escaping the bombs of World War II and a temporary translocation to the Soviet Union as war booty, the architectural collection and the entire Pergamon Museum became part of the GDR's East Berlin ${ }^{9}$. Since 2013, twenty-three years after the German reunification, the Museum is undergoing substantial renovation. Therefore, in 2012, the architectural collection was moved to a temporary storage and lab facility at the outskirts of Berlin. Despite or, perhaps, precisely because of this eventful history, many pieces of the architectural

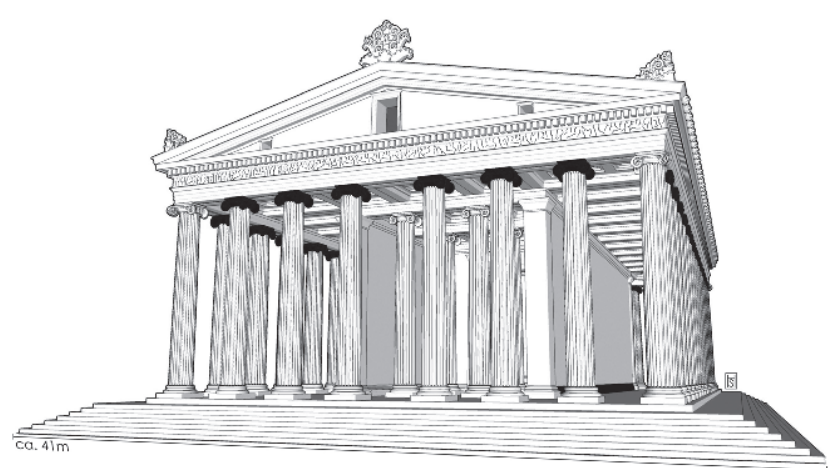

Fig. 3. Digital reconstruction of the temple of Artemis Leukophryene with potential locations of the investigated fragments highlighted in black. Courtesy S. Holzman.

collection, especially those that were never exhibited, seem to have been spared of historical conservation methods including the notorious "whitewashing" of marble surfaces. Fragments A and B, for example, still show the remains of earth from the excavation site in the depth of some ornamental undercuttings. Our surface analysis confirmed the absence of cleaning and conservation treatment. Overall, these are uniquely favorable conditions for a scientific colour analysis.

\section{Methodology}

The investigation began with a mapping of all surface phenomena that were visible with the naked eye (fig. 4). Three main categories were differentiated: 1) traces of surface working, meaning the visible marks of mason's tools on the stone surface as well as areas that showed traces of brushstrokes - behind this stands the intention to study the possible relationship between surface preparation and colouring; 2) different damages to the stone surface including weathering phenomena; and finally, 3) any kind of coating, which, at this observational stage, entailed both natural and anthropogenic coatings.

A few fundamental insights were gained during this initial stage of the analysis. On fragment A, a grey, flaky coat is present on only one half of the piece. It appears to be the result of weathering (fig. 4, categories "flaking surface" and "grey"). Therefore, this side of the columnar capital must have faced outwards, meaning it was exposed to wind-driven rain. The other side, which faced the cella, was much better protected from weathering; it shows, however, a series of washouts and dripping lines, which suggest that water regularly seeped from the above-lying architrave onto the capital ${ }^{10}$. As we will see later, the fact that all exterior capitals had a better visible exterior (front) and a less visible interior side also played a role for the application of colour (fig. 3).

After surface mapping, optical documentation was undertaken using a digital microscope (Keyence VHX-500FD) as well as a stereo-microscope (Zeiss SteREO V8) for spots, which 

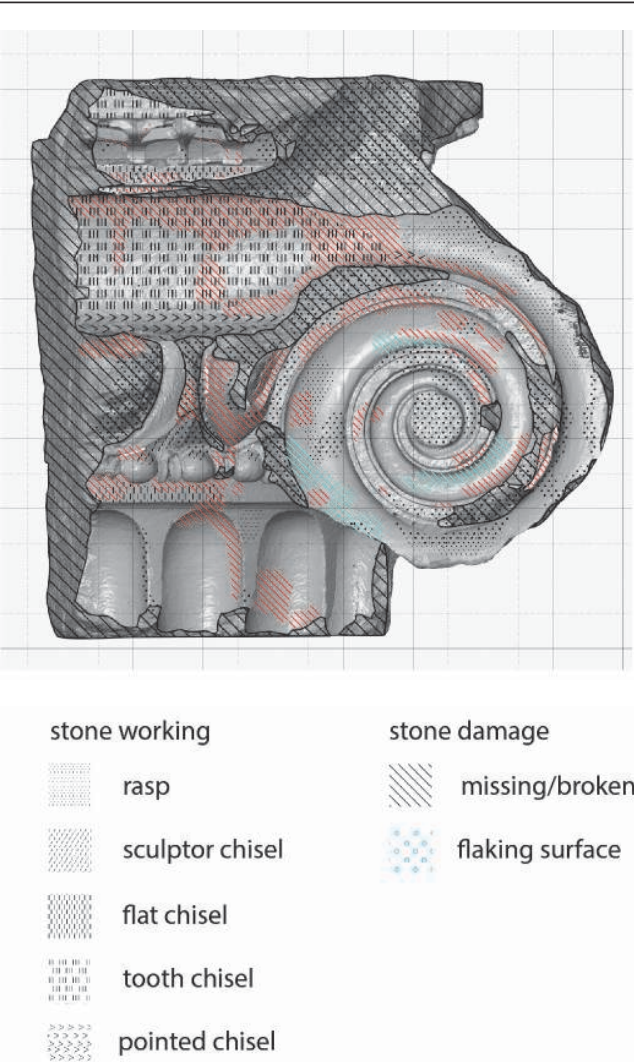

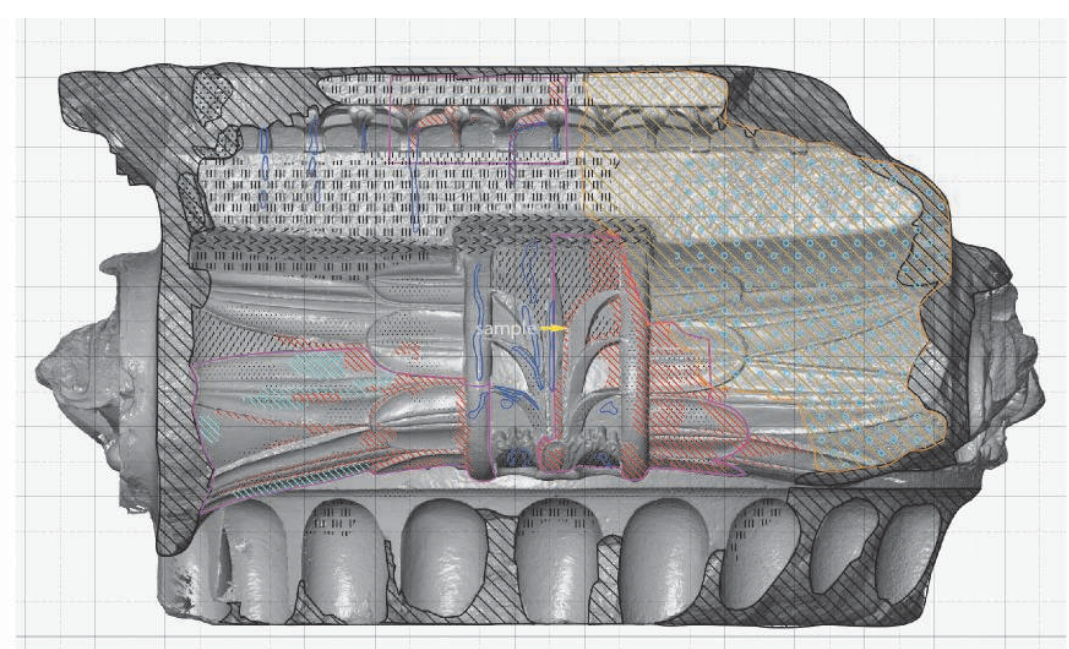

coatings (natural and anthropogenic)

white

mortar

multiple colours

grey

washouts

sinter crust

Fig. 4. Example of surface mapping on a structured light scan, here fragment A. The mapping includes all surface phenomena that were observed with the naked eye (raster size $0.1 \times 0.1 \mathrm{~m}$ ). ( ) Antikensammlung, Staatliche Museen zu Berlin.

required extra depth of field. Overall, 30 find spots were microscopically examined on fragment $\mathrm{A}, 16$ spots on fragment $\mathrm{B}$, and 8 spots on fragment $\mathrm{C}$ (fig. 2). Other non-invasive techniques that were applied included UV reflectography and VIL imaging - the latter, however, revealed not a single trace of Egyptian blue, and this will be significant for our final assessment of the colour scheme. Further, a handheld p-XRF was used to analyze a total of 30 spots $^{11}$. At a later stage of the project, macro-XRF scanning showed elemental distributions on surface segments of up to a few square centimeters (fragment A: 10 measurements; fragment B: 4 measurements; fragment C: 6 measurements) ${ }^{12}$. Eventually, from each fragment, a micro-sample was taken and thin sections produced in order to investigate the surface stratigraphy under the microscope.
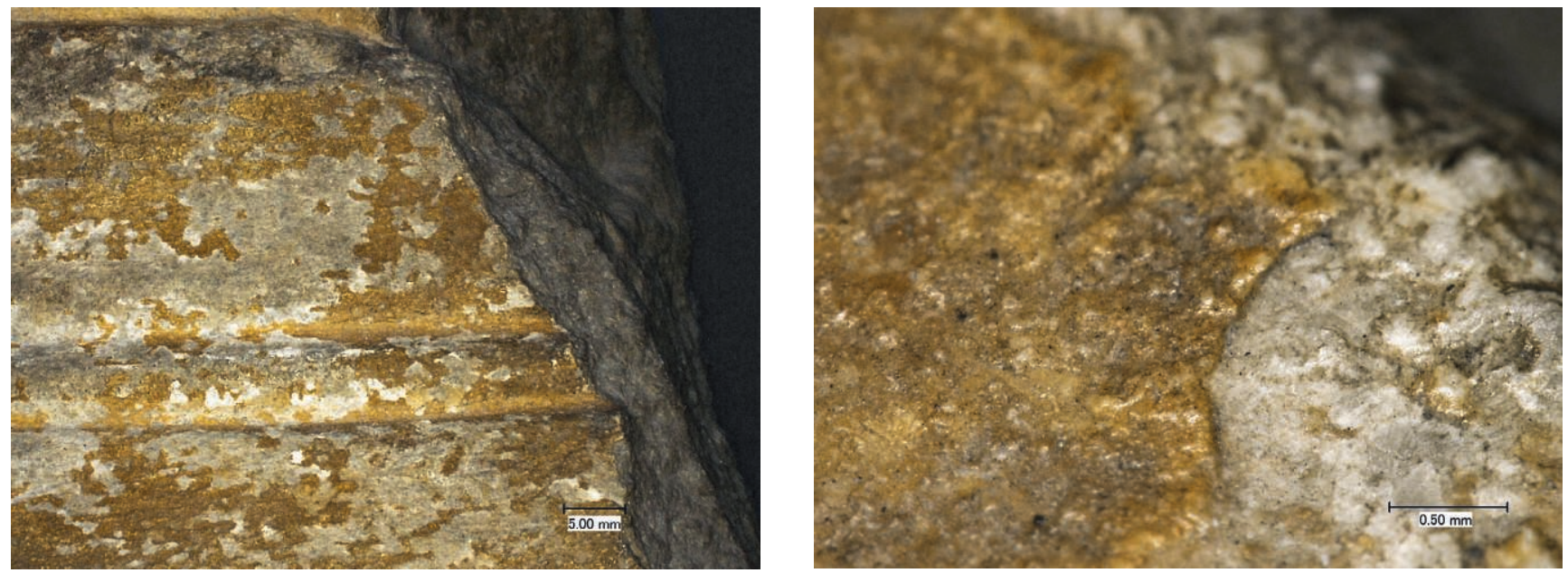

Fig. 5. Microscopy of fragment C, leaf pattern with three layers: a white primer and, on top, two different hues of yellow (left: 5x; right: 100x magnification; point m06 in fig. 2). (- Antikensammlung, Staatliche Museen zu Berlin. 
The samples were analyzed with environmental scanning electron microscopy (ESEM-EDX), Fourier-transform infrared spectroscopy (FT-IR) and Raman spectroscopy ${ }^{13}$. The overall data that was gathered from all this exceeds by far the scope of this paper. Therefore, we focus here only on the most important surface phenomena that were observed during surface mapping and present a selective synthesis of their elemental analysis. From a methodological point of view, the results obtained from the analysis of the three surface samples have to be prioritized as they provide the most reliable data set. It is the base of the assessment of the multitude of pigment-related elements that were evidenced through XRF-measurements.

\section{The yellow coatings}

Yellow coatings with changing hues from brownish to reddish yellow are visible with the naked eye, especially on fragment C but also on A (fig. 5); and according to elemental analysis, they were also present on B. It is remarkable that the yellow coatings appear predominantly on ornamental features. On the capitals (fragments A and B), they are present on the bolster leaves, the balteus decoration, the egg and dart pattern of the echinus, and the bead and reel molding below it (fig. 4, category "multiple colours"). They also cover the leaf pattern that decorated the base of the cella wall (fragment C); only in this case, they seem to have covered also the undecorated, vertical parts. The stratigraphic composition, the pigment mixtures, as well as the colour hues of the yellow coatings are not uniform, even if there is a basic similarity. Both microscopy and cross-sections of samples revealed multiple layers and various elemental analyses suggested the use of two different types of pigments as the base for the yellow: goethite or orpiment. They were mixed with white and either black or red pigments.

Fragment $\mathrm{C}$ has the most contingent remains of its yellow coating, which still covers about half of the leaf pattern. Microscopy and the cross-section of a sample show that it was composed of three layers (fig. 6): a lower, white layer (S1), and two layers above (S2 and S3), the latter both with white and yellow particles, as well as smaller amounts of either black or red. Raman, ESEM and FT-IR suggest that the uppermost layer (S3) contained large amounts of iron, which was identified as yellow ochre containing goethite. Along with this, traces of a black C-containing pigment were found, probably carbon black (Raman). The layer below (S2) revealed, next to yellow goethite, also some red hematite (Raman). In both layers (S2 and S3), the pigments were embedded in a white medium, which seems to be a mix of gypsum (calcium sulfate; Raman, ESEM) and magnesite (magnesium carbonate; ESEM, FT-IR). In all layers, electron microscopy showed the presence of magnesium, probably magnesium carbonate (marble powder). In the lowest layer (S1), which was nearly white, next to magnesium carbonate, the white pigment gypsum was also found (ESEM, Raman), as well as particles with a calcium phosphate spectrum (ESEM, Raman, FT-IR) that compares to hydroxyl-apatite, perhaps bone white ${ }^{14}$.

MA-XRF (Macroscopic X-ray fluorescence) at the same spot revealed a more diverse palette of pigment-related elements, but their interpretation is not unequivocal (fig. 7). Some of the additional elements may simply be "environmental noise", meaning elements from within the stone or from the archaeological context. In any case, MA-XRF also confirmed a strong presence of iron, which is probably related to the presence of goethite and hematite. In addition, it brought to light some manganese, the oxide of which was commonly used as a dark pigment ${ }^{15}$. Significant concentrations of zinc and lead were also detected, which seem to be of relevance as they appear also in other measurements (see below). A possible interpretation is the addition of zinc white 

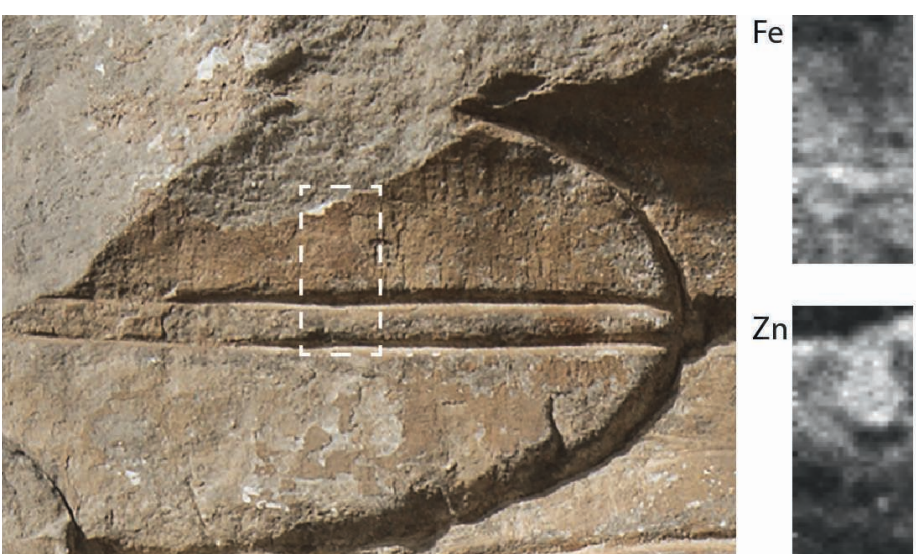

$\mathrm{Mn}$

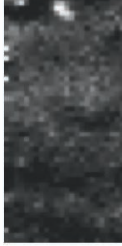

$\mathrm{Zn}$

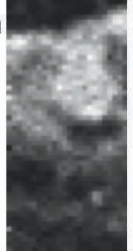

$\mathrm{Pb}-$

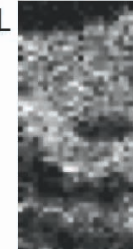

the same goethite Raman spectrum. As Raman analysis refers to a tiny spot in the micrometre range, it is possible that it revealed only a part of the mineral phases that were present; and goethite could be a minor component in the red layer, which thus could not be identified unambiguously. In addition, the white pigment magnesite is present throughout the sample, which suggests magnesium carbonate (marble powder), as on the sample from fragment $\mathrm{C}$; and white particles within both the yellow and red layer match with hydroxyl-apat-

20

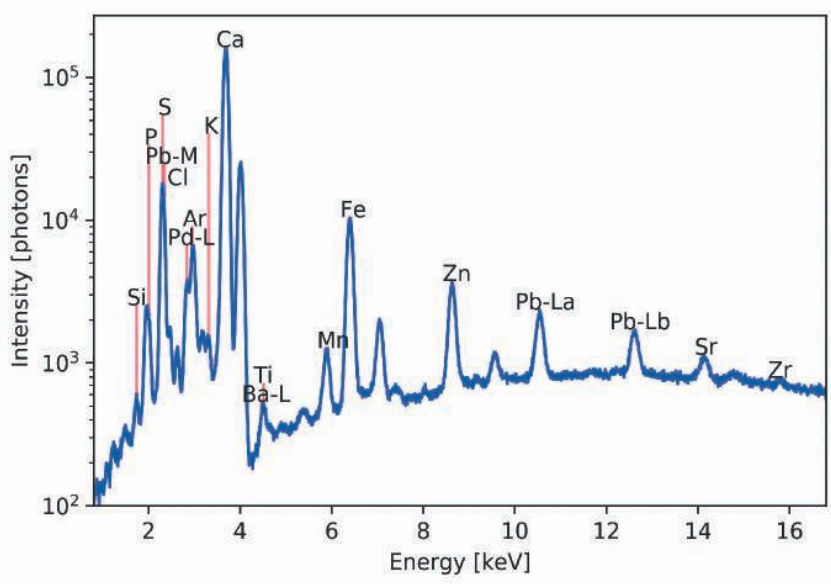

Fig. 7. Fragment C, results of Macro-XRF scanning on a leaf (dashed rectangle); light hues in the scans indicate high concentration. (C) Antikensammlung, Staatliche Museen zu Berlin.

(zinc oxide) and lead white (lead carbonate hydroxide) ${ }^{16}$. This would mean that the pigment mix was even more complex, with different whites and yellow, and some brown, black and red.

Turning to capital fragment A, we find a similar elemental composition, along with some interesting hints on the painting technique. The cross-section of a sample from the lateral bead of the balteus shows no clear stratigraphy but multiple overlapping and intersecting layers in yellow and red (fig. 8). In this case also, Raman spectroscopy suggests the presence of yellow ochre containing goethite. Remarkably, the red layers show ite, possibly bone white (fig. 8). MA-XRF at the same spot of fragment A revealed iron, manganese and zinc. These elements were also traced on all the other vegetal parts of the capital (central acanthus leaf of the balteus, bolster leaves, egg and dart as well as bead and reel moldings). For the most part, therefore, the pigment mix that was traced on fragment $\mathrm{A}$ is similar to that found on fragment C. There is, however, a fundamental difference. MA-XRF also revealed arsenic on the decorative elements of fragment $A$, thus suggesting the use of orpiment (arsenic trisulfide) ${ }^{17}$. Apparently, this brightest and most gold-like of all yellow pigments was reserved for the capitals and added to its most prominent and "sculptural" decorative features.

\section{The white coating}

On capital fragment A, the remains of a homogeneous white coating are preserved in the depth of the volute as well as in the channels of two columnar flutes (fig. 9 left). It is homogeneous in colour and texture, and it was applied directly on the finely worked marble surface. Under the microscope, the white coating appears rather thick and in a white-cream colour. In lack of a sample, we have to rely on the results of MA-XRF, which, and this has to be stressed, allows only a preliminary identification of the pigments (fig. 9). It revealed high concentrations of iron and sulfur as well as manganese, zinc, some lead and little calcium. The strong iron content speaks for the presence of an iron oxide pigment and, given the colour of the coating, it must have been rather light, perhaps a light-yellow ochre with some calcium-containing white (calcium carbonate or calcium sulfate). Possibly, these were mixed with manganese pink (manganese carbonate from rhodochrosite), zinc white (Zinc oxide) and lead white (lead carbonate hydroxide) to achieve a creamy white colour ${ }^{18}$.

Both the pigment-related elements and the appearance of the white coating differ from a thick, white-grey sinter crust, which covered both broken and
Fig. 8. Fragment A, balteus; cross-section of a sample with multiple overlapping and intersecting layers in red and yellow, such as a-d (for the sample spot, see fig. 2). (C) Antikensammlung, Staatliche Museen zu Berlin. 
original surfaces (fig. 4; fig. 10). It shows signals of calcium, strontium and zirconium, which are elements that probably originate from local soils ${ }^{19}$. Most likely therefore, the sinter crust results from the specific geo-archaeological conditions of the site, meaning the alluvial depositions of the nearby Maeander river, which had regularly swamped the ruin ${ }^{20}$. In contrary to the sinter crust, the white coating was a mix of several pigments to achieve both the desired colour tone as well as a colour that was stable enough for exposure to the elements. Probably, its purpose was to homogenize the color of the fine-grained white marble with its light and dark veins ${ }^{21}$. Specific ornamental features, however, were rendered separately with yellow coatings, although here too, a mix of white played a role as primer.

\section{Painterly rendering}

We have previously seen the use of differently coloured and overlapping layers on a sample from capital fragment A (fig. 8). Both microscopy and cross-sections of other decorative features revealed a similarly variable stratigraphy on several ornamental decorations. It can be interpreted as painterly colour rendering, which uses changing colour hues to create naturalism, depth, shading, and highlights.

When looking at the bolster of capital fragment A, we find, on a single leaf, different stratigraphic situations right next to each other, for example, the transition from a dark brown layer to a yellow layer on a white primer (fig. 11, point m12). Towards the center of the leaf (fig. 11, m01), however, we see only the light-yellow layer on the white primer; and a few centimeters next to it (fig. 11, m03), a yellow layer has a red instead of a white primer. Another spot (fig. 11, m16) shows that the primer for the yellow layer could change between brown/red and white. Other multicoloured and

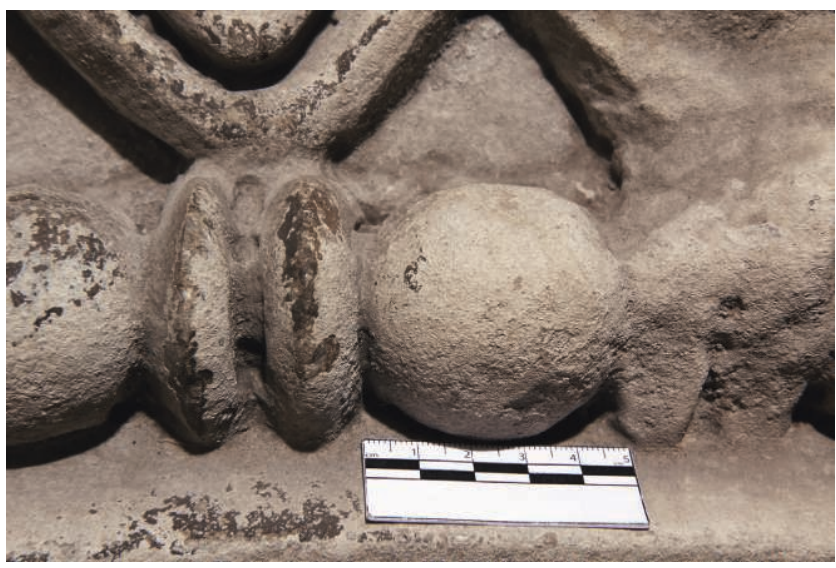

Fig. 10. Sinter crust on fragment B, probably from alluvial depositions of the nearby Maeander river. (C) Antikensammlung, Staatliche Museen zu Berlin.

changing layers of brown/yellow and white/yellow are present on the adjacent leaves. These observations suggest that the leaves were not painted in a uniform colour but with changing and merging colour hues. An interesting detail is preserved at the lower part of the balteus of fragment A (fig. 12): the highest part of the bead shows a white/grey patch, which follows the contours of the bead. At the sides (and towards the back), it fades into a dark brown to reddish brown and yellow. This could be a painted highlight or a reflection.

These techniques of painterly rendering seem to have been applied to decorative elements such as leaves, palmettes and moldings (bead and reel, egg and dart). The changing colour hues as well as painted shadows and highlights suggest the naturalistic rendering of a specific material. Given the overall presence of yellow with reddish to brown areas, it seems likely that the imitated material was freshly cast or gilded bronze.
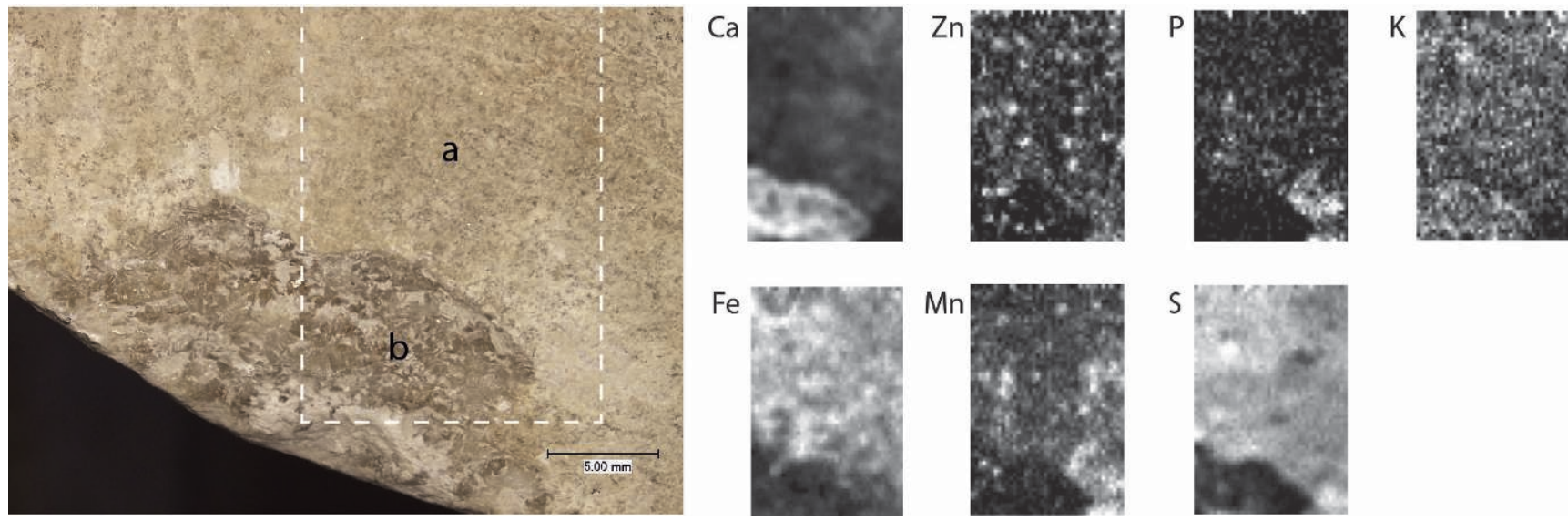

Fig. 9. Left: microscopy of fragment A, volute (point m12 in fig. 2) with remains of a white coating (a) next to a break in the marble surface (b); right: Macro-XRF scans of the white coating (dashed rectangle in left image). (c) Antikensammlung, Staatliche Museen zu Berlin. 

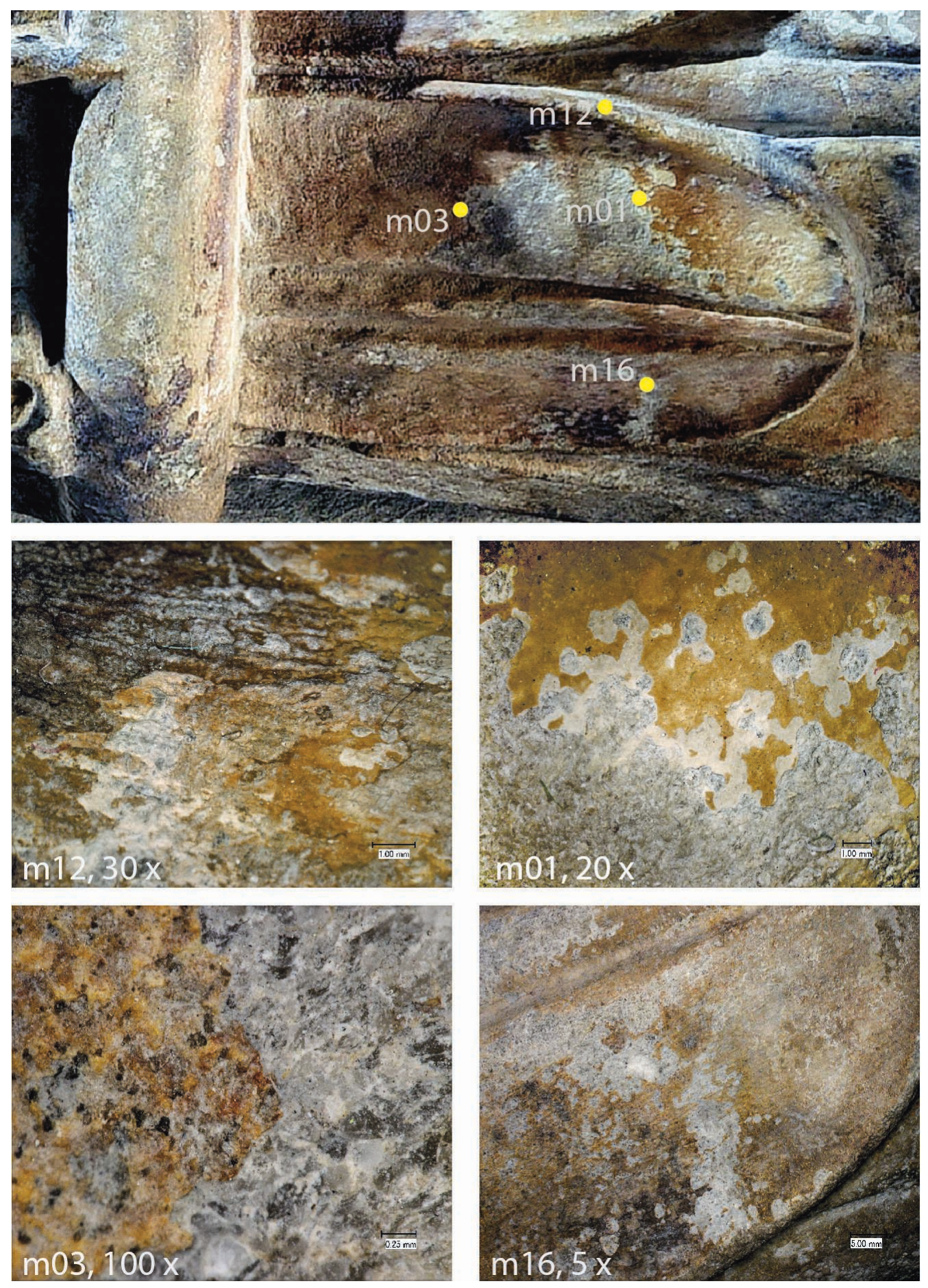

Fig. 11. Fragment A,

complex stratigraphy on a bolster leaf with multiple layers and merging color hues (for location, see fig. 2). () Antikensammlung, Staatliche Museen zu Berlin. 


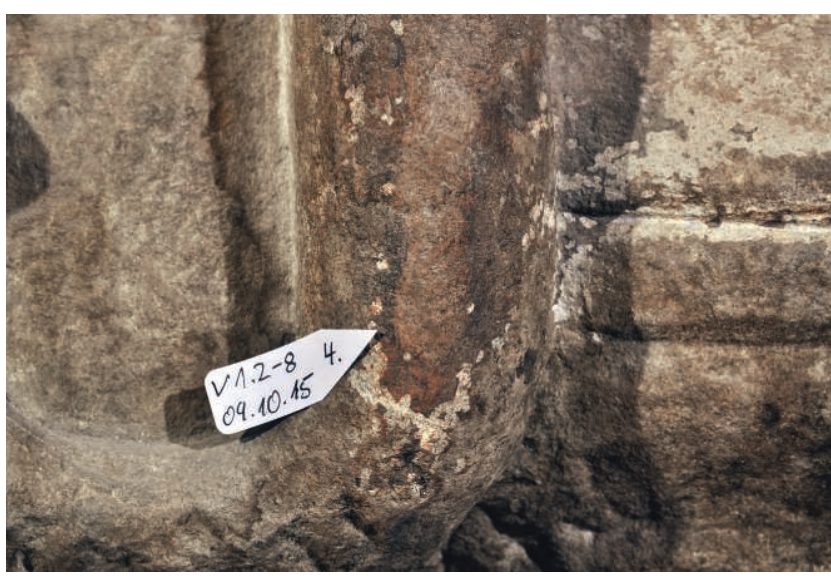

Fig. 12. Fragment A, lateral bead of the balteus; the highest part shows a white/grey area, which fades into darker hues, perhaps a painted highlight. () Antikensammlung, Staatliche Museen zu Berlin.

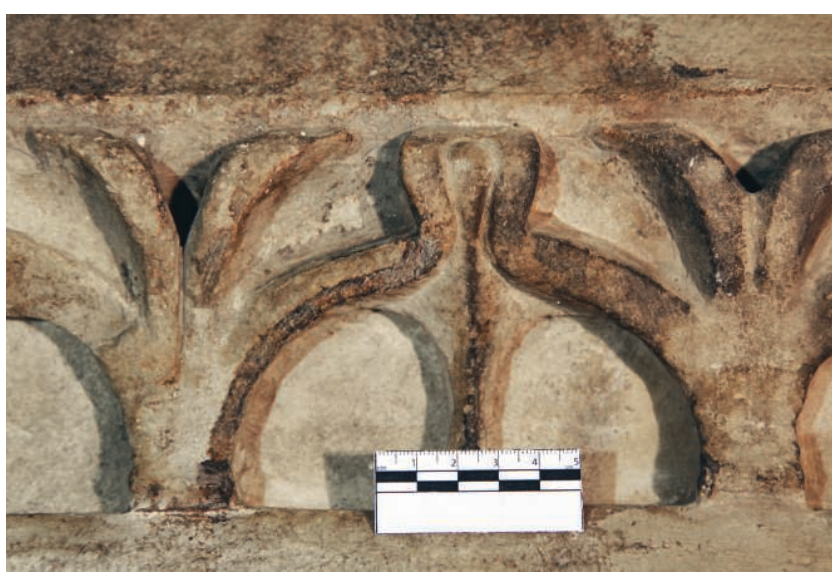

Fig. 13. Fragment A, Lesbian cyma on the abacus with contour lines of varying width, probably applied with respect to original viewing angles. (C) Antikensammlung, Staatliche Museen zu Berlin.

\section{Contour and shadow lines}

In addition to the application of a homogenizing white coating and the painterly rendering in multiple colour hues to imitate metal, we observed a third method of painted surface rendering: the tracing of ornamental features with lines to accentuate contours and/or enhance shadow effects. Clear traces of regularly applied contour lines are visible with the naked eye on the Lesbian cyma of the abacus (elemental composition remains to be examined; fig. 13). The lines are painted directly on the raised parts of the ornament. Remarkably, they are not symmetrical, as the line on the right side of the leaf was thicker. This asymmetry may explain itself when considering the spatial context of the capital in the temple's pteron (fig. 3). The side that was accentuated with contour lines faced away from the cella and was thus exposed to direct sunlight (evidence for weathering phenomena indicate this, as the surface mapping revealed; cf. above). Moreover, this exterior side was perceived from afar when approaching the building. Therefore, the purpose of the painted shadow/contour accentuation may have been to counterbalance the different perception of ornamental features in the sunlit and shaded parts and thus guarantee even plasticity and depth. Similar contour accentuations were found on the spiral of the volute, which itself was rendered in white; its slightly elevated fillet was accentuated on top and in the interior side with a red-brown-black line that was more or less $4 \mathrm{~mm}$ wide (fig. 14).

\section{The result in context}

We have seen that the carved ornaments on both the exterior capitals and the cella wall were either accentuated with colour or their surfaces fine-tuned with an off-white coating. On ornaments such as leaves, palmettes and various moldings (egg and dart, Lesbian cyma, bead and reel), colour rendering used rather complex pigment mixtures to create intricate hues and thus achieve naturalistic surface effects including shading and highlighting. The predominant use of yellow-brown-red colour hues suggests that the goal was to imitate, in painting, the colour of freshly cast bronze or gold. Representations of bronze elements on Roman wall paintings show how yellow-brown-red colour hues, painted shadows, and highlights were used to imitate freshly cast and gilded bronze elements (fig. 15). Jörg Denkinger's hand drawn reconstruction of the polychromy of capital fragment A departs primarily from the results of surface analysis, but also uses analogies from wall paintings to recreate the lost visual complexity (fig. 16). Of course, such a reconstruction comes with a good deal of extrapolation. Moreover, the hand drawing can only be the first preliminary method of reconstruction, and others, for example digital methods, would lead to different visual results.

Overall, our findings correspond rather well to what we know about the architectural polychromy of the Hellenistic period when architectural surfaces began to adopt techniques of illusionistic painterly rendering that were previously developed in panel painting. A good comparison for the illusionistic painting of ornaments on a marble façade can be found on the Ptolemaion at Limyra ${ }^{22}$. So far, however, these techniques have never been attested on a marble temple of monumental size. For a monumental temple façade, also the applied colour palette is rather surprising. It includes predominantly yellow, brown, red and white/cream hues yellow seems to have been especially prominently used. Blue, usually a standard architectural colour, is entirely missing, and also red only appears in mixtures with yellow. This suggests that the temple's colour scheme did not correspond to the colour scheme of white (or cream), dark (blue or black) and red (or purple), which had dominated Doric and Ionic temple facades since the Archaic period ${ }^{23}$. This colour triad remained a fixed part of Ionian temple design also during the Hellenistic period. The architect Pytheos, for example, applied the scheme for the columnar façade of his famous 


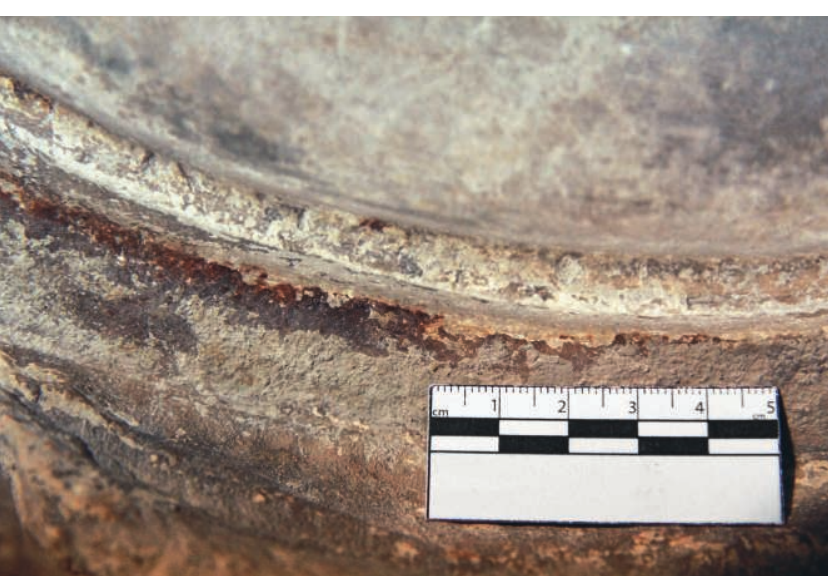

Fig. 14. Fragment A; black-brown-red contour lines along the volute to accentuate its shape (point m28 in fig. 2). (c) Antikensammlung, Staatliche Museen zu Berlin.

Ionic temple of Athena at Priene; and it was found on the exterior of both the temple of Apollon at Didyma and the Mausoleum at Belevi ${ }^{24}$. Apparently, the façade of Hermogenes' temple of Artemis connects to a fundamentally different chromatic tradition, which used shiny bronze or gold in combination with white marble. In all this, we have to keep in mind that it is impossible to say with certainty when the white-yellow colour scheme was applied to the façade of the Artemision. The cross-sections of surface samples speak for an application of the colour scheme shortly after the temple was finished as they do not show any depositions or erosion between the marble surface and the painting layers. Therefore, we may assume that the yellow/gold and white color scheme was part of Hermogenes' original design, even if the temple was probably finished only after the death of its $\operatorname{architect}^{25}$.

When looking at the development of architectural polychromy, we can see that the colour combination of white and yellow/gold had a long tradition. On exterior facades, gilded metal sheeting and the application of gilded metal attachments

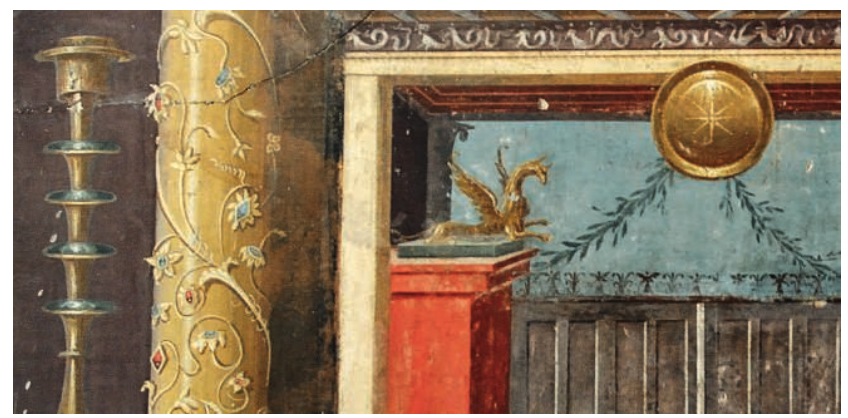

Fig. 15. Bay of Naples/Oplontis, Villa A, Triclinium 14 (around mid-1st century A.D.), wall painting with representations of various metal elements in freshly cast or gilded bronze. Note the changing color hues and the white patches to render light reflection and highlights on round surfaces. (C) D. Esposito. are known since the Archaic period. The earliest known examples of exterior architectural gilding are the capital volutes of the Archaic Artemision at Ephesos; and Corinthian bronze capitals appeared on facades since the Late Classical period ${ }^{26}$. During the Hellenistic period, interior architectural members often featured colour schemes of yellow and/or gold in combination with marble and other precious materials. Corinthian capitals from the Nile Delta and the Southern Levant, for example, regularly apply dark red, purple, yellow, white, and gilding. Scholars noted that such colour schemes corresponded to literary descriptions of Ptolemaic architecture (such as Athenaios' description of Ptolemy IV's floating palace) but also to representations on Roman wall paintings, which often show gilded metal architecture ${ }^{27}$.

Altogether, our interpretation of the colour evidence from the Magnesian temple of Artemis as an imitation of bronze applications fits into a wider phenomenon of ancient architectural polychromy. We should, however, not forget that most of the temple's exterior surfaces were probably kept off-white (such as the column shafts); and therefore, it seems to have been the combination of white with bronze that was the guiding principle of the colour scheme. Hermogenes' innovation may have been to apply this scheme on a monumental scale and to the exterior of one of Ionia's large marble temples. It is possible that this innovative design foreshadowed the aurea templa, the golden temples, which later became a hallmark of Imperial Rome ${ }^{28}$.

There are, however, many factors which still limit our understanding of the temple's colour scheme. Unknowns concern not only the original colour rendering, on which we only have a glimpse, but also the ornamental syntax, which remains to be reconstructed. In fact, the ornaments of both columnar bases and capitals show variations: the capitals' bolsters could be decorated with either palm or acanthus leaves and the balteus with a palmette or with festoons. On some capitals (perhaps from the front?), the volute eyes featured drill holes, perhaps for the attachment of bronze rosettes ${ }^{29}$. In order to regain the original colour scheme, we would have to examine the polychromy of the different capital designs, and we would have to determine both their correct position on the building as well as the light exposure of their different viewsides. Then, of course, there is the temple's 175-meter-long frieze, of which a few parts are today in Berlin and many in Istanbul as well as Paris. The frieze is remarkable for its high relief, which seeks stark contrasts of light and shadow - we can only wonder now if and how it was accentuated in colour, especially in concert with the architectural colour scheme. Were its figures also rendered as an imitation of bronze?

The fact that we can even formulate such questions speaks for the success of this project, which had the simple goal of finding out whether the Berlin pieces preserve any interesting remains of ancient surface treatment. The Prussian removal of the fragments from the excavation site and their immediate storage in Berlin were a loss for the archaeological site, but for research on architectural polychromy, this early removal now becomes a unique 


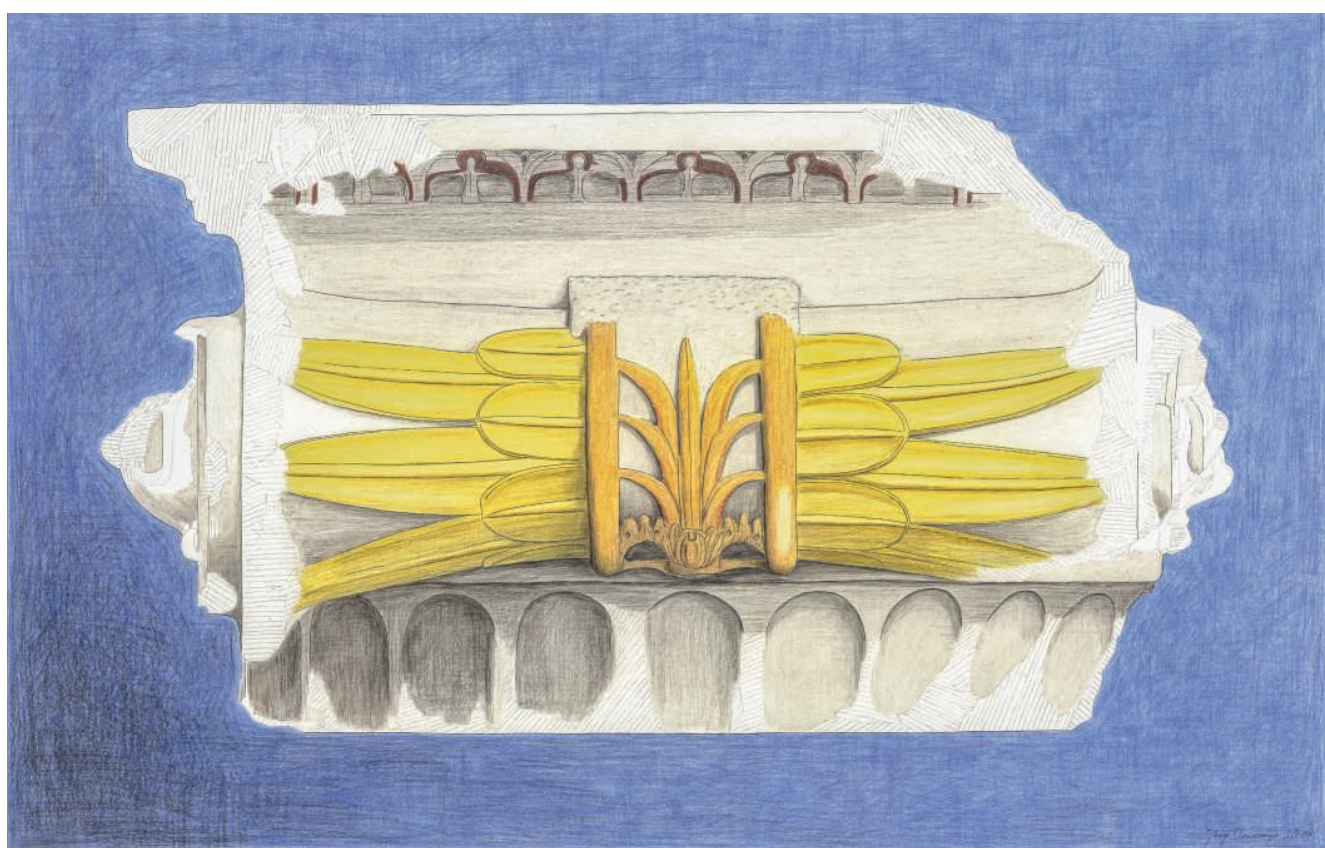

Fig. 16. Measured hand drawing of capital fragment A (H. Bücherl) with tentative reconstruction of the polychromy according to the results of surface analysis (J. Denkinger). ( German Archaeological Institute, Berlin.

opportunity - it preserved many architectural surfaces which, on the site, are today lost to erosion and weathering. Of course, museum storage does not, by default, mean proper protection, but in the case of the Berlin fragments, we are in the fortunate position that they escaped not only the bombs of World War II, but also past inadequate conservation treatment. Therefore, the Berlin-fragments of the Temple of
Artemis now represent a unique repository of knowledge on architectural surface treatment. From this perspective, future research could turn the 19th century stripping of the archaeological site into an advantage and gain from the fact that, precisely because of their diverse modern lifetimes, the temple's fragments in Magnesia, Berlin, Istanbul, and Paris, preserve information of different qualities.

\section{Notes}

1. For the state of knowledge on ancient architectural polychromy, see now Zink, 2019, with extensive bibliography.

2. On the scope of the project Taschner, Zink, 2016. Both the initiative for this project and organizational support came from Monika Trümper (FU Berlin), Ulrike Wulf-Rheidt + (DAI Berlin) and Martin Maischberger (Antikensammlung, Staatliche Museen zu Berlin) to all of whom we express our gratitude. The Berliner Antike Kolleg/Einstein Foundation and the Swiss National Science Foundation provided financial support. For feedback, we thank Brigitte Bourgeois (Centre de Recherche et de Restauration des Musées de France), Lothar Haselberger (Univ. of Pennsylvania) and the anonymous reviewers, as well as S. Holzman (Univ. of Pennsylvania) for the $3 \mathrm{D}$ rendering in fig. 3 .

3. Most recently Haselberger, Holzman, 2015; comprehensively now Haselberger, 2020.

4. Kohte, 1904, p. 80: "Von der farbigen
Ausstattung des Tempels ist nichts überliefert."

5. Humann, 1904, p. 2-3.

6. See also Kohte, 1904, p. 66, note 1 .

7. Photographs and 3D Laserscans of our project are available under http:// repository.edition-topoi.org/collection/ MAGN/ (29.07.2019); fragment B appears in Kohte, 1904, p. 57, fig. 40; for fragment C, see Kästner, 2013, p. 274-275, p. 282, fig. 2, 3. For the marble type, see note 21.

8. Exterior and interior columns can clearly be separated; the latter are slightly shorter, not fully finished, and the bolsters of the capitals lack the leaf decoration (Kohte, 1904, p. 56, p. 80).

9. Heilmeyer, 2018, p. 11-26.

10. The regularity of weathering phenomena speaks against their development after the collapse of the temple.

11. F. Kutz (TOPOI Berlin and Free University of Berlin, Institute of Geographical Sciences) carried out this measurement.

12. On the method and a recent example of its application, see Alfeld et al., 2018.

13. IR-spectrometer Paragon 1000 PC with FT-IR microscope Perkin Elmer; Raman: Horiba XploRa.

14. Eastaugh et al., 2004, p. 246-247, s.v. Magnesite; p. 190, s.v. Hydroxylapatite.

15. Eastaugh et al., 2004, p. 251, s.v. Manganese Oxides and Hydroxides Group.

16. Eastaugh et al., 2004, p. 377-378, s.v. Umber; p. 233-235 s.v. Lead White; p. 406407 s.v. Zinc Oxide.

17. Eastaugh et al., 2004, p. 285-286, s.v. Orpiment.

18. See note 16 ; in addition, Eastaugh et al., 2004, p. 251 s.v. Manganese White; for white earths, see also Siddall, 2018, p. 10-12.

19. On elements in the sediments of the Büyük Menderes river, also before industrialization and the beginning of pesticide application (a state, which applies to our fragments as removed from the site between 1891 and 1893), see Akcay et al., 2003.

20. The site had to be drained before the Prussian excavations in the early 1890 s 
(Humann, 1904, p. 3).

21. The white marble of the capitals and entablature comes from a quarry about $20 \mathrm{~km}$ North of Magnesia; for isotopic analysis, see Cramer, 2004, p. 205-208 p. 210; Cramer's work is also summarized in Heilmeyer, 2007, p. 139, p. 155-156 (note $78)$, p. 159-160.

22. Stanzl, 2015, p. 183-184, fig. 13

23. Hellmann, 2002, p. 230, 232; Zink, 2019, p. 6-7, p. 11; for the so-called Archaic color triad, Walter-Karydi, 1986.

24. Rayet, Thomas, 1880 , p. $80-81$;

Praschniker et al., 1979 , p. 64, 68, Pl. 49a; Koenigs, 2015, p. 41-43.

25. For a summary of the chronological problems surrounding the temple's construction, see Rumscheid, 1994, p. 25-28 O. Bingöl has recently argued for a basis of an inscription; in the same article, however, the epigraphist B. Dreyer refuted this interpretation, see Bingöl, Dreyer, 2018 , p. 68-71 (Bingöl) and p. 76 (Dreyer contra Bingöl).

26. Ephesos: Jenkins, 2006, p. 38, fig. 19; Corinthian bronze capitals: overview in Scahill, 2009.

27. Foerster, 1995 , p. 112-113;

McKenzie, 2007, p. 103.

28. Gros, 1976 , p. 40-41; Zink with Piening, 2009

29. On these differences, see Kohte, 1904, p. 53-56, fig. 36-37.

\section{Bibliography}

Akcay H., Oguz Unver A., Varlikli C., 2003, "Study of heavy metal pollution and speciation in Buyak Menderes and Gediz river sediments", Water Research 37, p. 813-822.

Alfeld M., Mulliez M., Devogelaere J., de Viguerie L., Jockey P., Walter P., 2018, "MA-XRF and Hyperspectral Reflectance Imaging for Visualizing Traces of Antique Polychromy on the Frieze of the Siphnian Treasury", Microchemical Journal 141, p. 395-403. doi: 10.1016/j.microc.2018.05.050

Bingöl O., Dreyer B., 2018, "Neues zu Magnesia, archäologisch und epigraphisch", in H. Frielinghaus, T. Schattner (eds.), Ad summum templum architecturae. Forschungen zur antiken Architektur im Spannungsfeld der Fragestellungen und Methoden, Möhnesee, p. 61-86.

Cramer T., 2004, Multivariate Herkunftsanalyse von Marmor auf

petrographischer und geochemischer Basis das Beispiel kleinasiatischer archaischer, hellenistischer und römischer Marmorobjekte der Berliner Antikensammlung und ihre Zuordnung zu mediterranen und anatolischen Marmorlagerstätten (Dissertation Technical University of Berlin 2004, accessible online).

Eastaugh N., Walsh V., Chaplin T., Siddal R., 2004, The Pigment Compendium. A Dictionary of Historical Pigments, Oxford \& Burlington, Massachusetts.

Foerster G., 1995, Masada V: The Yigael Yadin Excavations 1963-1965, Final Reports, Art and Architecture, Israel Exploration Society, Jerusalem.

Gros P., 1976, Aurea templa: recherches sur l'architecture religieuse de Rome à l'époque d'Auguste, École française de Rome, Rome.

Haselberger L., Holzman S., 2015, "Visualizing asperitas: Vitruvius (3.3.9) and the 'asperity' of Hermogenes' pseudodipteral temple", Journal of Roman Archaeology 28, p. 371-392.

Haselberger L., 2020, Der Pergamonaltar und der Architekt Hermogenes. Schatten, Raum und Wahrnehmung, G. Reimer, Berlin.

Heilmeyer W.-D., 2007, "Berliner Marmore aus Kleinasien. Bericht über ein geologisch-archäologisches Projekt 1994-2004", Jahrbuch des Deutschen archäologischen Instituts 122, p. 127-161.

Heilmeyer W.-D., 2018, Geteilte Antike - Die Berliner Antikensammlung im geteilten Deutschland, Berliner Schriften zur Museumsforschung 35, Holy Verlag, Berlin.

Hellmanm M.-C., 2002, L'Architecture grecque. 1, Les Principes de la Construction, Picard, Paris, p. 229-256.

Humann C., 1904, Magnesia am Maeander: Bericht über Ergebnisse der Ausgrabungen der Jahre 1891-1893, G. Reimer, Berlin.

Jenkins I., 2006, Greek Architecture and its Sculpture in the British Museum, British Museum Press, London.

Kästner V., 2013, "Die Cellamauern des Artemistempels von Magnesia am Mäander", in Orhan Bingöl'e 67. yaş armağanı (Kızılay, Ankara: Bilgin Kültür Sanat Yayıncılık), p. 273-287.

Koenigs W., 2015, Der Athenatempel von Priene, Reichert, Wiesbaden.

Kohte J., 1904,"Die Bauwerke”, Humann, p. $9-163$.

McKenzie J., 2007, The Architecture of Alexandria and Egypt: c. 300 B.C. to A.D. 700, Yale University Press, New Haven.

Praschniker C. et al., 1979, Das Mausoleum von Belevi, Österreichisches
Archäologisches Institut, Wien.

Rayet O., Thomas A. A., 1880, Milet et le Golfe Latmique, vol. 2, J. Baudry, Paris.

Rumscheid F., 1994, Untersuchungen zur kleinasiatischen Bauornamentik des Hellenismus, P. v. Zabern, Mainz.

Scahill D., 2009, "The Origins of the Corinthian Capital”, in P. Schultz (ed.), Structure, Image, and Ornament. Architectural Sculpture in the Greek World, Proceedings of an International Conference held at the American School of Classical Studies, 27-28 November 2004, Oxbow, Oxford, p. 40-53.

Siddall R., 2018, "Mineral Pigments in Archaeology: Their Analysis and the Range of Available Materials", Minerals $8(5)$.

Stanzl G., 2015, "Das Ptolemaion von Limyra”, in J. des Courtils (ed.), L'Architecture monumentale grecque au III siècle av. J.-C., Ausonius Éditions, Bordeaux, p. 184.

Taschner M. et al., 2016, "Architectural Fragments from Magnesia, Staatliche Museen zu Berlin - Antikensammlung", Edition Topoi, http://repository. edition-topoi.org/collection/MAGN/ (accessed 14.10.2019)

Taschner M., Zink S., 2016, “Magnesia am Mäander in der Berliner Antikensammlung. Neue Ansätze zur Erforschung antiker Architektur", Antike Welt 2, 2016, p. 35-37.

Walter-Karydi E., 1986, "Prinzipien der archaischen Farbgebung", in Studien zur Klassischen Archäologie, Festschrift Friedrich Hiller, Saarbrücker Dr. u. Verl., Saarbrücken, p. 23-41.

Zink S., 2019, "Polychromy, architectural, Greek and Roman", in S. Goldberg (ed.), Oxford Classical Dictionary (New York: Oxford University Press) - online @ http://oxfordre.com/classics/ on March 27, 2019.

Zink S., with Piening H., 2009, "Haec Aurea Templa: The Palatine temple of Apollo and its polychromy", Journal of Roman Archaeology 22, p. 109-122.

\section{Unpublished document}

Egel, E., Aibéo C., Reiche, I., 2016 Architekturteile Artemis-Tempel in Magnesia am Mäander (heutige Westtürkei), Rathgen Forschungslabor Staatliche Museen zu Berlin, Untersuchungsbericht $101 \quad 120915$ (23.03.2016) and 81_080116a (25.08.2016). 